\title{
PELATIHAN PEMBUATAN MAKANAN RINGAN EKSTRUDAT JAGUNG GUNA MENINGKATKAN PENDAPATAN MASYARAKAT
}

\section{TRAINING OF SNACK EXTRUDED MAIZE TO IMPROVE INCOME}

\author{
${ }^{1)}$ Muh Amin, ${ }^{2)}$ Muhammad Subri \\ ${ }^{1,2)}$ Program Studi Teknik Mesin, Fakultas Teknik \\ Universitas Muhammadiyah Semarang \\ J1. Kedungmundu Raya No. 18 Semarang \\ email: amin@unimus.ac.id
}

\begin{abstract}
ABSTRAK
Tujuan pengabdian masyarakat ini adalah untuk meningkatkan pendapatan masyarakat petani jagung di Dukuh Plosokerep Desa Prawoto Kecamatan Sukolilo Kabupaten Pati. Pentingnya pengabdian masyarakat ini karena pada awalnya seluruh petani jagung di Plosokerep menjual hasil panennya berupa jagung pipilan basah (tanpa diproses lebih lanjut) sehingga memiliki nilai jual yang relatif rendah. Maka dari itulah perlu dilakukan penyuluhan dan praktek pengolahan produk dari bahan baku jagung. Pada pengabdian ini telah berhasil dilakukan penyuluhan dan praktek pembuatan makanan ringan ekstrudat jagung. Pelaksanaan pengabdian masyarakat dilakukan diawali dengan sosialisasi dan penyuluhan tentang produksi makanan ringan ekstrudat jagung. Setelah itu dilakukan praktek dan pendampingan dalam produksi sampai dihasilkan produk siap jual. Hasil yang diperoleh adalah masyarakat mitra mampu memproduksi makanan ringan ekstrudat jagung secara mandiri. Setelah pengabdian ini dilakukan, masyarakat mitra sudah mulai tergerak akan pentingnya pengolahan hasil pertanian karena sudah merasakan meningkatnya pendapatan.
\end{abstract}

Kata kunci: Pelatihan, Pembuatan Makanan Ringan, Ekstrudat Jagung

\begin{abstract}
The purpose of community service to increase the income of corn farmer's community in Plosokerep, Prawoto Village, Sukolilo District, Pati Regency. The importance of community service is caused initially all corn farmers in Plosokerep sells their crops in the form of wet popping corn (without further processing) so it has relatively low selling value. Therefore, it is necessary to do counseling and product processing practices from corn raw materials. In this service has been successfully done counseling and the practice of making extruded snack from corn. Implementation of community service is initiated by socialization and counseling about the production of maizeextruded. Furthermore, practiced and continuous mentoring until partners are able to produce it ready to sell. The result is the partner community is able to produce maize extruded snack independently. After the dedication has been done, the partner community has begun to be moved on the importance of agricultural processing because it has felt the increase in income.
\end{abstract}

Keyword: Training, Production Of Snack, Corn Snack, Maize Extruded

Submited : 27 Juli 2017

Revision : 25 Februari 2018

Accepted : 5 Maret 2018

\section{PENDAHULUAN}

Dukuh Plosokerep Desa Prawoto Kecamatan Sukolilo Kabupaten Pati terletak di sebelah selatan wilayah
Kabupaten Pati dan berbatasan langsung dengan wilayah Kabupaten Grobogan. Plosokerep merupakan sebuah perdukuhan yang berjarak $5 \mathrm{~km}$ dari desanya yang terhalang oleh hutan milik pemerintah 
daerah. Berdasarkan wawancara dengan Kepala Dusun Plosokerep, Muslikhah, bahwa Dukuh Plosokerep yang terdiri dari 10 RT, 641 Kepala Keluarga (KK) dan 1858 Jiwa ini memiliki lebih dari $90 \%$ warganya (usia dewasa) tidak tamat sekolah dasar dengan mata pencaharian sebagai petani jagung.

Lahan pertanian di Dukuh Plosokerep berupa pegunungan batu kapur tanpa ada saluran irigasi. Oleh karena itu pertanian yang dapat dilakukan di dukuh tersebut adalah dari jenis palawija. Masyarakat Dukuh plosokerep lebih memilih menanam jagung daripada tanaman yang lain. Lahan pertanian tanpa irigasi ini dapat dilakukan penanaman jagung jagung sebanyak tiga kali dalam setahunnya. Rata-rata masyarakat Dukuh Plosokerep memiliki lahan seluas (1/4 - 1/2) Hektar dengan rata-rata hasil panen jagung setiap panen sebanyak (1-2) ton. Harga jual lokal jagung pipilan basah dalam setiap kilogram adalah (Rp 2.300,- sampai dengan $\mathrm{Rp} 2.700,-)$ sedangkan harga jual jagung pipilan kering dengan kadar air 20 dalam setiap kilogram adalah $(\mathrm{Rp} 3.000$,sampai dengan Rp 3.200,-).

Hasil panen jagung dapat ditingkatkan harga jualnya dengan cara dilakukan proses lebih lanjut terlebih dahulu, misalnya dengan dibuatnya menjadi makanan ringan atau yang lain. Meskipun hasil panen jagung merupakan sumber penghasilan utama bagi mayoritas masyarakat Dukuh Plosokerep, akan tetapi masyarakat Dukuh Plosokerep lebih memilih menjual hasil panen jagung tanpa diproses lebih lanjut (biasanya jagung dijual dalam kondisi pipilan basah) sehingga pendapatan masyarakat Dukuh Plosokerep relatif masih rendah.

\section{METODE}

Peningkatan pendapatan masyarakat di Dukuh Plosokerep yang kurang memiliki jiwa kewirausahaan adalah dengan diberikannya pelatihan pembuatan makanan ringan ekstrudat dari bahan baku lokal yaitu jagung. Pelatihan diawali dengan penyuluhan tentang kewirausahaan untuk menggugah pikiran masyarakat agar tidak terpaku pada hasil pertanian jagung yang dijual tanpa melalui proses terlebih dahulu sehingga harga jualnya menjadi rendah.

Selain penyuluhan tentang kewirausahaan, oleh tim pelaksana yang dibantu dengan Mahasiswa Universitas Muhammadiyah Semarang (UNIMUS) juga memberikan penyuluhan tentang proses produksi makanan ringan ekstrudat dari jagung. Setelah diberikan pengetahuan tentang proses produksi, mitra IbM yang di pimpin oleh Bapak Sunanto dan Bapak Nuryanto dilakukan pendampingan dalam melakukan proses produksi.

Sebelum dilakukan proses produksi, tim pelaksana IbM telah memberikan peralatan berupa mesin ekstrudat dengan penggerak daya listrik 900 Watt, alat pengering minyak (spinner) dan hand sealer.

Setelah proses produksi selesai, dilakukan pengemasan produk. Selain itu pemasaran produk juga diberikan pelatihan baik secara offline maupun online. Salah satu media pemasaran online yang cukup baik untuk zaman sekarang ini adalah dengan membangun sebuah website. Oleh karena itulah pada pengabdian masyarakat ini mitra juga dibuatkan sebuah website yang berguna untuk memasarkan produk secara lebih luas lagi.

\section{HASIL DAN PEMBAHASAN}

Hasil kegiatan ini adalah :

1. Mitra memiliki pandangan cara meningkatkan pendapatan dari mengolah bahan baku jagung menjadi makanan ringan ekstrudat jagung. 
Muh Amin, Muhammad Subri

Pelatihan Pembuatan Makanan Ringan Ekstrudat Jagung

Guna Meningkatkan Pendapatan Masyarakat

2. Mitra memiliki pendapatan tambahan disamping menjual jagung dalam kondisi pipilan basah.

3. Mitra memiliki kemampuan dalam memproses produksi makanan ringan ekstrudat jagung.

4. Mitra memiliki kemempuan memasarkan produk dengan memanfaatkan website.

5. Makanan ringan ekstrudat yaitu makanan ringan yang dibuat melalui proses ekstrusi dari bahan baku dengan penambahan bahan lain yang diijinkan dengan atau tanpa melalui proses penggorengan (Badan Standardisasi Nasional, 2000).Ekstusi yaitu suatu proses dimana bahan dipaksa olehsystem ulir untuk mengalirkan dalam suatu ruangan yang sempit sehingga akan mengalami pencampuran dan pemaksaan sekaligus seperti pada Gambar 1 berikut ini :

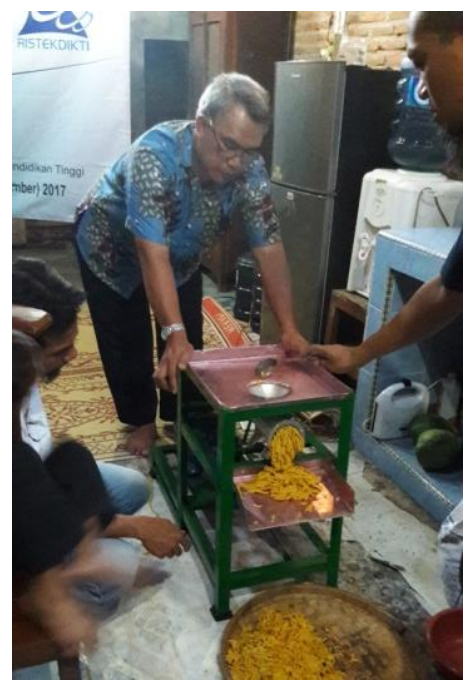

Gambar 1. Proses Esktruder Jagung

Efek dari ekstrusi adalah panas akibat gesekan antara bahan dan ulir. Menurut Oktavia (2007) keuntungan dari proses ekstrusi adalah produktivitas tinggi, bentuk sangat khas dan banyak variasinya.
Setelah diproses dengan menggunakan alat ekstruder, bahan baku hasil ekstrusi dikeringkan dengan cara diangin-anginkan dengan menggunakan sebuah kipas guna seperti pada Gambar 2
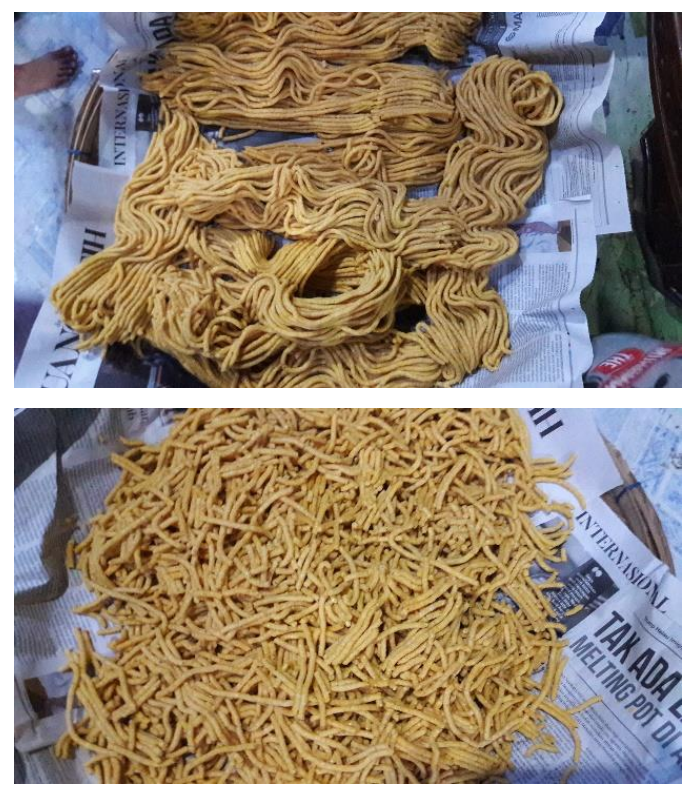

Gambar 2. Hasil Ekstrusi

Setelah diangin-anginkan selama 15 menit, bahan baku dapat dilakukan penggorengan dengan minyak. Setelah ditiriskan dengan mesin spinner, hasil penggorengan sudah siap untuk dilakukan pengemasan seperti pada Gambar 3 . Pengemasan dengan menggunakan hand sealer untuk merekatkan pembungkus plastik. Pemberian label ditempatkan pada bagian atas dan terpisah dengan produk dengan harapan minyak yang kemungkinan masih menempel di produk tidak dapat terserap ke label yang terbuat dari kertas. Hasil pengemasan produk yang sudah siap untuk dipasarkan adalah seperti pada Gambar 4. 


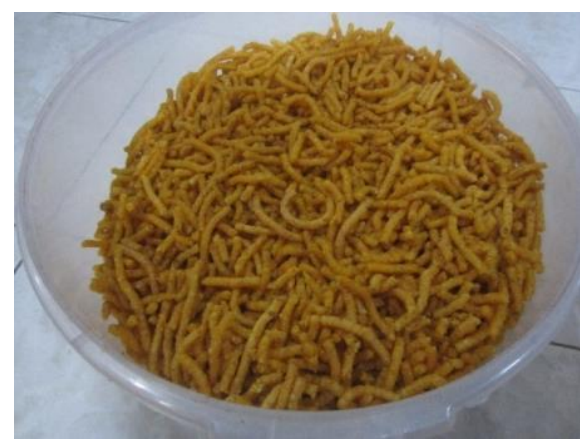

Gambar 3. Produksi Makanan Ekstrudat Jagung setelah Proses Penggorengan dan Penirisan Minyak

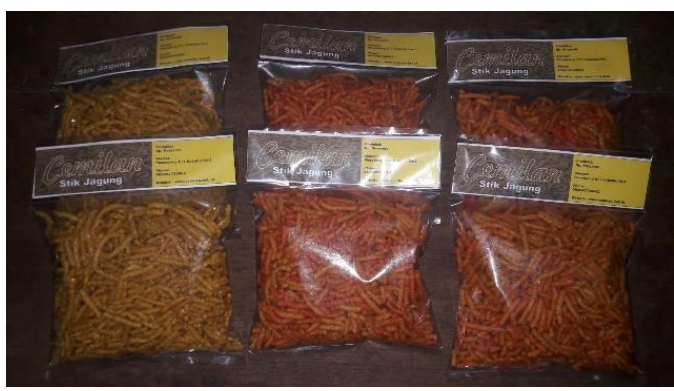

Gambar 4. Hasil Produksi Makanan Ekstrudat Jagung Siap Jual

Jagung (Zea mays L.) merupakan bahan baku yang dapat dijadikan sebagai bahan baku pembuat berbagai makanan ringan yang diminati oleh kebanyakan anak-anak. Selain itu makanan ringan dari jagung memiliki kandungan gizi yang cukup tinggi, selain sebagai sumber karbohidrat, jagung juga merupakan sumber protein yang penting. Jagung juga kaya akan komponen pangan fungsional, termasuk serat pangan yang dibutuhkan tubuh, asam lemak esensial, isoflavon, mineral ( $\mathrm{Ca}, \mathrm{Mg}, \mathrm{K}, \mathrm{Na}, \mathrm{P}, \mathrm{Ca}$ dan $\mathrm{Fe}$ ), antosianin, betakaroten (provitamin A), komposisi asam amino esensial, dan lainnya (Suarni dan Yasin, 2011). Meskipun demikian, masyarakat Dukuh Plosokerep belum banyak yang dapat memanfaatkan hasil panen utama mereka sebagai bahan baku pembuat makanan ringan.

\section{SIMPULAN}

Dengan diberikannya pelatihan dan praktek proses produksi makanan ringan ekstrudat jagung di lokasi mitra, mitra menjadi lebih menguasai dan faham sehingga mitra dapat memproduksi makanan ringan ekstrudat jagung secara mandiri. Namun demikian, tim mitra IbM masih melakukan peninjauan pada saat-saat tertentu guna memastikan kemampuan mitra.

\section{UCAPAN TERIMAKASIH}

Terimakasih kepada KemenristekDikti dan LPPM Unimus yang telah memberikan kesempatan dan support dana dalam pelaksanaan program Iptek bagi Masyarakat (IbM)

\section{DAFTAR PUSTAKA}

Badan Standardisasi Nasional, (2000), SNI 01-2886-2000 Makanan Ringan Ekstrudat, Jakarta.

Oktavia D.A, (2007), Kajian SNI 012886-2000 Makanan Ringan Ekstrudat, Jurnal Standardisadi 9, (1), 1-9.

Suarni dan Yasin, (2011), Jagung sebagai Sumber Pangan Fungsional, IPTEK TANAMAN PANGAN, 6 (1) 